\title{
全国寄生虫学討 論会
}

中国动物学会于 1963 年 11 月 24 日一-12月 1 日在北京码开了全国寄生虫学专业討諭会。出席 会議的代表 67 人，列席者百余人。会議由中国医 学科学院馮兰洲敎授致开幕詞。动物学会理事长秉 志教授向大会致賀詞。国家科委范长江副主任泣会 作了重要报告。这次会議洪收到諭文 244 篇，会議 除了检閱研究成果和交流工作經驗外，还进行了寄 生虫学发展問題的討論。

在家畜寄生虫方面，有关血狍子虫的种类和分 布研究，已积累了大量資料，同时还掌握了流行病 学上的特点，为防治工作暯定了良好的基础。对于 猪腎虫病，通过形态、生活史及流行病学的研究， 提出以春季幼虫不发育时培养后备母猪或采用二次 治疗、二次隔离以及結合綜合措施的方法培养康复 母猪翌，为发展养猪事业作出了貣献。羊寄生虫病 的区䒺調查，全国各地已先后开展，其中新疆維吾 尔自治区的綿羊寄生虫病已基本上調查清楚，为合 理控制綿羊寄生虫病的蒙延，提出了科学的根据。

在魚类答生虫方面, 近年来有了迅速的发展, 在“环境因子对淡水魚类等生虫影响”的报告中，初 步明确了物理、化学、生物、空闌、时間等环境因 子与魚类寄生蚁采的从属关系，可以利用寄生虫

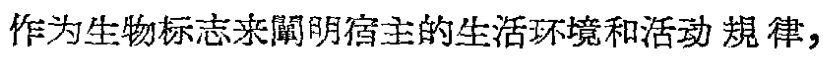
对防治工作有一定的指导意义。两种盾㪄吸虫生活 史的比較㸴究和两种腹口旪虫生活史的㸴究均具有 很高的水本。盾盘吸虫亚綱在吸虫分类上具有重要 的位置, 且过去研究甚少, 而它又界于单殖类和复 殖类之間，对了解吸虫的系統发生問題，有着重要 的价値。

在人体寄生虫方媔，对于利什曼原虫病的研 究，在甘肃、新疆等地的沙漠中发現大沙鼠感染利 什曼原虫，后經严密的动物实驗，証明該虫不同于 苏联沙漠中的热带利什曼原虫，对人无害，从而閪 明了与我国黑热病的传播无关。有的論文指出，寄

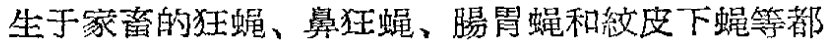
能传染到人而引起病淀，因而明确了防治家畜及野 生动物的寄生虫病，对保証人体健康具有重婯的意 义。关于日本血吸虫病的研究, 进一步严清了血吸 虫病的流行情况，促进了防治方法的完善。对于非 人体血吸虫病尾䗥所引起的箘田性皮资問題，也在 流行情况、发展机制和防护措施等方面犾得不同程 度的結果。在利用犬鈎虫作为試驗材料測定鈎虫吸 血量, 結果与 Roche 等 (1960)的試驗数据相接近, 从而証实了以前敎科书所引用的 Wells 氏 (1931)的 数据是錯䛊的。

应用新技术从事寄生虫学的研究, 已作出了一 定的成績。

关于抹殖吸虫的分类問題，在会上展开了不同 見解的孚論。通过斯氏科殖、四川䢁殖的形态比 較，生活史研究，以及霍蚫的覌察等論文报告，对 抹值吸虫的秀統分类和皮棘可否作为分类特征等問 题有了更进一步的訏識。在討論中对此虽有不同的 意見，但一致䚯为，建立新种应該进一步从形态、 生活史、免疫等多方面深入磁究，以促进我国扭殖 吸虫研究的发展。

这次会議还举行了f个专題报告。如哭光敎授 的“我国几种自然瘦源性的蝡虫病”、溤兰洲呚授的 “人、畜寄生虫在传染上的相互关采”、陈心陶㸚授 的“蠕虫病的中枢神經抹发症”、唐仲璋教授的“病 原生物学与人、畜寄生虫的相互关䒺”、毛守白敎 授的“近年来血吸虫病血清贺疫学研究的进展”等， 都是从多年累积資料中，总結的精华，概括地䦥迹了 近年来我国寄生虫学的研究进展, 也指出了笴生虫 学今后的发展。

此外，代表們还对新种的命名、发表、模式标 本的保管、交献与标本的交換等問題进行了該諭。

[沈守訓] 